\title{
Wyłączenie samorządowych organów podatkowych oraz ich pracowników - uwagi de lege lata oraz de lege ferenda
}

\author{
The exclusion of local tax authorities and their \\ employee - de lege lata and de lege ferenda remarks
}

Streszczenie. Przedmiotem opracowania jest analiza regulacji prawnych dotyczących wyłączenia samorządowych organów podatkowych od załatwienia spraw podatkowych oraz ich pracowników od udziału w postępowaniu podatkowym, zmierzająca do oceny obowiązujących rozwiązań oraz zaproponowania zmian w tym zakresie. Jako wymóg państwa prawnego należy bowiem uznać konieczność obowiązywania regulacji przewidujących wyłącznie organu oraz jego pracowników we wszystkich tych sytuacjach, w których pojawi się ryzyko niezachowania obiektywizmu (zgodnie z zasadą nemo iudex in causa sua). Przeprowadzona analiza regulacji prawnych prowadzi do wniosku, że ze stosowaniem przepisów dotyczących wyłączenia samorządowych organów podatków oraz ich pracowników związane są liczne problemy, a regulacje te nie znajdują zastosowania we wszystkich tych sytuacjach, w których pojawia się ryzyko braku bezstronności organu lub jego pracowników. W ocenie autora wadliwość analizowanych unormowań wynika z faktu, iż ustawodawca, konstruując przepisy, nie 
uwzględnił specyfiki samorządowych organów podatkowych. W opracowaniu zaproponowano zamiany legislacyjne przepisów dotyczących wyłączenia organów podatkowych oraz ich pracowników, w wyniku których zwiększona zostanie gwarancja bezstronnego działania administracji podatkowej.

Słowa kluczowe: organ podatkowy; wyłączenie organu podatkowego; wyłączenie pracownika organu podatkowego; samorządowe kolegia odwoławcze.

\begin{abstract}
This article aims to analyse legal regulations concerning the exclusion of local tax authorities from the settlement of tax matters and their employees from participating in tax proceedings, to assess existing solutions and to propose changes in law. The analysis of legal regulations has led the author to the conclusion that the application of the provisions concerning the exclusion of local government taxes and their employees are related to numerous problems, including these regulations do not apply in all those situations where there is a risk of lack of impartiality of the tax authorities or its employees. In the author's opinion analysis of legal regulation led to the conclusion that legislator do not take into account the specificity of local tax authorities. The study proposes the conversion of legislative provisions relating to the exclusion of tax authorities and their employees, which resulted in increased activity will guarantee a fair tax administration.
\end{abstract}

Keywords: tax authorities; exclusion of tax authorities; exclusion employee of a tax authorities; self-government board of appeal.

\title{
1. Wstęp
}

Przedmiotem niniejszego opracowania jest analiza regulacji prawnych dotyczących wyłączenia samorządowych organów podatkowych od załatwienia spraw podatkowych oraz ich pracowników od udziału w postępowaniu podatkowym, która zmierza do oceny obowiązujących rozwiązań oraz zaproponowania zmian w tym zakresie. Uzasadniając wybór problematyki, należy wskazać, że wójt, burmistrz oraz prezydent miasta są jednocześnie samorządowymi organami podatkowymi I instancji oraz podmiotami projektującymi i wykonującymi budżet jednostki samorządu terytorialnego, co może wywoływać wątpliwości co do ich bezstronności we wszystkich prowadzonych postępowaniach. Istotnym dochodem bu- 
dżetu gminy są bowiem ustalane lub określane przez te organy dochody z tytułu podatków lokalnych, co może wywoływać uzasadnioną obawę odnośnie do zachowania przez nich w toku postępowania podatkowego jego zasad, w tym zasady prawdy obiektywnej. Konieczne wydaje się zatem, by obowiązujące regulacje przewidywały wyłącznie organu podatkowego oraz jego pracowników we wszystkich tych sytuacjach, w których na skutek tego, że zobowiązanie podatkowe dotyczy gminy, pojawia się ryzyko niezachowania przez nich obiektywizmu (zgodnie z zasadą nemo iudex in causa sua). Jednocześnie obowiązujące regulacje, które wzorują się na rozwiązaniach ustawy z dnia 14 czerwca 1960 r. Kodeks postępowania administracyjnego ${ }^{1}$, wzbudzają wątpliwości w praktyce ich stosowania i wydają się nie odpowiadać w pełni wymogom postępowania podatkowego.

\section{Charakterystyka regulacji dotyczących wyłączenia samorządowych organów podatkowych oraz ich pracowników}

Konieczność obowiązywania przepisów dotyczących wyłączenia organów podatkowych oraz ich pracowników wynika z wymogu zagwarantowania obiektywizmu ich działań w toku postępowania oraz zasad praworządności i prowadzenia postępowania podatkowego w sposób wzbudzający zaufanie do organów podatkowych ${ }^{2}$.

Obowiązujące przepisy przewidują w wybranych sytuacjach wyłączenie z mocy prawa samorządowych organów podatkowych I instancji, które skutkuje utratą kompetencji do załatwienia przez nie spraw i ich przeniesienia do organu o innym zakresie właściwości terytorialnej. Na podstawie art. 132 § 1 ustawy z dnia 29 sierpnia 1997 r. - Ordynacja podatkowa ${ }^{3}$, wójt oraz burmistrz (prezydent miasta), ich zastępcy oraz skarbnicy jednostek samorządu terytorialnego podlegają wyłączeniu od

Tekst jedn. Dz.U. z 2013 r. poz. 267 ze zm., dalej: k.p.a.

H. Dzwonkowski, Z. Zgierski, Procedury podatkowe, Warszawa 2006, s. 717.

Tekst jedn. Dz.U. z 2012 r., poz. 749 ze zm., dalej: Ordynacja podatkowa. 
załatwienia spraw dotyczących ich zobowiązań podatkowych lub innych spraw normowanych przepisami prawa podatkowego. Zgodnie z art. 132 $\S 2$ Ordynacji podatkowej, § 1 powołanego wyżej przepisu stosuje się do małżonki, rodzeństwa, wstępnych, zstępnych albo powinowatych pierwszego stopnia osób wskazanych w § 1 oraz osób związanych stosunkiem przysposobienia, opieki lub kurateli z tymi osobami. W myśl art. 132 § 3 Ordynacji podatkowej w przypadku wyłączenia organu samorządowe kolegium odwoławcze wyznacza w drodze postanowienia organ właściwy do załatwienia sprawy. Należy stwierdzić, że wyznaczając właściwy organ, samorządowe kolegium odwoławcze ograniczone jest w wyborze do właściwych rzeczowo organów podatkowych I instancji. Wadliwe uznanie, że organ podatkowy podlegał wyłączeniu i rozstrzygnięcie jej przez inny organ skutkuje wydaniem rozstrzygnięcia z naruszeniem przepisów o właściwości ${ }^{4}$.

Z kolei w sytuacji zaistnienia okoliczności, które potencjalnie podważają wiarygodność pracownika organu podatkowego, zastosowanie znajdują przepisy przewidujące jego wyłączenie od udziału w postępowaniu w konkretnej sprawie. Na podstawie art. 130 § 1 Ordynacji podatkowej pracownik urzędu gminy (miasta) oraz członek samorządowego kolegium odwoławczego podlegają wyłączeniu od udziału w postępowaniu w sprawach dotyczących zobowiązań podatkowych oraz innych spraw normowanych przepisami prawa podatkowego, w których zachodzą przypadki wymienione w pkt 1-8 tego przepisu (m.in. pracownik jest stroną lub pozostaje ze stroną w takim stosunku prawnym, że rozstrzygnięcie może mieć wpływ na ich prawa i obowiązki). Wyłączenie pracownika następuje wówczas z urzędu. Z kolei w sytuacjach niewymienionych w art. $130 \S 1$ pkt 1-8 Ordynacji podatkowej bezpośredni przełożony pracownika jest obowiązany na jego żądanie lub na żądanie strony albo z urzędu wyłączyć go od udziału w postępowaniu, jeżeli zostanie uprawdopodobnione istnienie okoliczności, które mogą wywołać wątpliwości co do bezstronności pracownika. W orzecznictwie sądowym podkreśla się, że interpretując art. $130 \S 1$ Ordynacji podatkowej, przepisy należy wykładać

4 Wyrok Naczelnego Sądu Administracyjnego z dnia 3 kwietnia 1990 r., SA/Wr 1001/89, ONSA 1990, nr 2-3, poz. 36. 
ściśle, a jego rozszerzająca wykładnia, obejmująca inne kategorie osób wyłączonych niż w nim wymienione, jest nieuprawiona ${ }^{5}$.

Powołane wyżej regulacje wywołują istotne wątpliwości co do zakresu ich stosowania m.in. w sytuacji wydania przez samorządowy organ podatkowy indywidualnej interpretacji przepisów prawa podatkowego, wyłączenia organu I instancji od załatwienia sprawy związanej w wymiarem zobowiązań podatkowych gminy oraz udziału w wydaniu rozstrzygnięcia w trybie nadzwyczajnym członka samorządowego kolegium odwoławczego, który brał udział w wydaniu rozstrzygnięcia w postępowaniu odwoławczym lub zażaleniowym.

\section{Wyłączenie wójta, burmistrza i prezydenta miasta od wydania interpretacji indywidualnej przepisów prawa podatkowego}

Zgodnie z art. 14j Ordynacji podatkowej stosowanie do swojej właściwości interpretacje indywidualne wydaje wójt, burmistrz (prezydent miasta), starosta lub marszałek województwa. Powołany przepis przewiduje obowiązek wydania przez samorządowe organy podatkowe I instancji interpretacji prawa podatkowego w sytuacji złożenia wniosku przez zainteresowanego. Na podstawie art. 14h Ordynacji podatkowej w sprawach dotyczących interpretacji indywidualnej stosuje się odpowiednio przepisy art. 120 , art. $121 \S 1$, art. 125, art. 129, art. 130, art. 135-137, art. 140, art. 143, art. $165 \S 3$ b, art. 165a, art. 168, art. $169 \S 1-2$, art. 170 i art. 171 oraz przepisy rozdziału 5, 6, 10 i 23 działu IV Ordynacji podatkowej.

Wątpliwość odnośnie do stosowania art. 14j Ordynacji podatkowej powstają wówczas, gdy wniosek o wydanie pisemnej indywidualnej interpretacji przepisów prawa podatkowego dotyczących podatków lokalnych złoży gmina. Sytuacja taka, jakkolwiek wydaje się wyjątkową, może pojawić się w związku z wątpliwościami co do interpretacji przepisów regu-

5 Wyrok NSA z dnia 30 maja 2005 r., I GSK 253/05, Centralna Baza Orzeczeń Sądów Administracyjnych (CBOSA). Podobnie S. Babiarz, B. Dauter, B. Gruszczyński, R. Hauser, A. Kabat, M. Niezgódka-Medek, Ordynacja podatkowa. Komentarz, Warszawa 2007, s. 515. 
lujących podatek od nieruchomości, w którym z uwagi na własność nieruchomości, podatnikiem może być gmina. Zaznaczyć należy, że wydanie interpretacji przepisów podatkowych zagwarantuje gminie, że do czasu jej zmiany przez Ministra Finansów w trybie art. 14e Ordynacji podatkowej, będzie ona wiążąca i skutkuje m.in. zwolnieniem z obowiązku zapłaty podatku, nienaliczaniem odsetek oraz brakiem możliwości prowadzenia postępowania karnoskarbowego (art. 14k i art. 14m Ordynacji podatkowej).

Co do zasady organem właściwym miejscowo i rzeczowo do wydania interpretacji przepisów podatkowych w zakresie podatków lokalnych od nieruchomości położonych na terenie gminy jest wójt tej gminy lub burmistrz bądź prezydent miasta. Naturalna wydaje się zatem konieczność wyłączenia w opisanej sytuacji faktycznej właściwego organu, ponieważ może on być zainteresowany wydaniem interpretacji przepisów na korzyść wnioskodawcy, tj. przykładowo stwierdzenia braku lub istnienia obowiązku zapłaty podatku. Podkreślić należy, że interes w odpowiedniej interpretacji przepisów prawa podatkowego przez samorządowy organ podatkowy może wynikać przy tym nie z chęci realnego zwiększenia wpływów podatkowych, który w analizowanym przypadku oczywiście nie nastąpi, ponieważ w sytuacji opodatkowania nieruchomości gminy brak jest przewłaszczenia środków pieniężnych na skutek zapłaty podatku. Samo uregulowanie $\mathrm{w}$ tej sytuacji podatku przez gminę nie ma zatem realnie wpływu na wysokość wpływów do budżetu (wydatek gminy związany z zapłaceniem podatku skutkuje uzyskaniem przez nią dochodu w tej wysokości). Jednocześnie wójt, jako organ wykonujący budżet, może być zainteresowany tym, by wykazywać jak najniższą wysokość dochodów podatkowych z tytułu podatków płaconych przez gminę, ponieważ w sytuacji zaniżenia wysokości uzyskanych dochodów podatkowych gmina otrzymuje wyższą kwotę subwencji ogólnej ${ }^{6}$. Kolejna kwestia wiążąca się $\mathrm{z}$ analizowanym problemem to ewentualna odpowiedzialność karnoskarbowa osoby odpowiedzialnej za złożenie deklaracji na podatek oraz uiszczenie podatku. Uzyskanie wiążącej interpretacji przepisów podatkowych, z której wynika nieistnienie obowiązku podatkowego pomimo, że obiek-

6 Zob. szerzej: T. Brzezicki, W. Morawski, Gmina jako podatnik podatku od nieruchomości, „Przegląd Podatków Lokalnych i Finansów Samorządowych” 2010, nr 10, s. 9. 
tywnie on istnieje, może stanowić podstawę do uniknięcia odpowiedzialności karnoskarbowej wójta bądź skarbnika w sytuacji, gdy zobowiązania nie zadeklarowano lub nie uiszczono.

Jednocześnie analiza obowiązujących przepisów prowadzi do wniosku, że nie przewidują one wyłączenia wójta, burmistrza lub prezydenta miasta w sytuacji złożenia przez gminę wniosku o wydanie interpretacji indywidualnej przepisów prawa podatkowego. Wskazane wyżej przepisy dotyczące interpretacji nie zawierają bowiem odesłania do przepisów Ordynacji podatkowej regulujących wyłączenia organu, lecz stanowią wyłącznie o odesłaniu do art. 130 Ordynacji podatkowej, przewidującego wyłączenie pracowników od udziału w postępowaniu. Zaznaczyć także należy, że niezależnie od wyraźnego braku odesłania w treści przepisów do art. 132 \& 1 Ordynacji podatkowej wyłączenie organu w opisanej sytuacji nie byłoby możliwe, ponieważ przepis ten przewiduje, że wójt, burmistrz (prezydent miasta), starosta, marszałek województwa, ich zastępcy oraz skarbnik jednostki samorządu terytorialnego podlegają wyłączeniu od załatwiania spraw dotyczących ich zobowiązań podatkowych lub innych spraw normowanych przepisami prawa podatkowego. Z kolei sprawa związana z wydaniem interpretacji na wniosek gminy przez jej wójta, burmistrza lub prezydenta miasta nie dotyczy „ich” zobowiązań lub innych spraw z zakresu prawa podatkowego. Rozważyć można, czy podstawą do wyłączenia wójta, burmistrza lub prezydenta miasta jest art. 130 § 1 pkt 2 Ordynacji podatkowej, który przewiduje wyłączenie pracownika urzędu gminy (miasta) w sytuacji pozostawania ze stroną w takim stosunku prawnym, że rozstrzygnięcie sprawy może mieć wpływ na ich prawa i obowiązki ${ }^{7}$. W tej sytuacji można bowiem uznać, że rozstrzygnięcie sprawy związanej z wydaniem indywidualnej interpretacji może mieć wpływ na prawa i obowiązki wójta, burmistrza lub prezydenta miasta jako osoby, która - przykładowo - składa deklarację na podatek oraz decyduje

\footnotetext{
7 Ponieważ wójt jest zatrudniony na podstawie wyboru w urzędzie gminy, do jego wyłączenia stosuje się art. $130 \S 1$ pkt 1-8 Ordynacji podatkowej - tak B. Brzeziński, M. Kalinowski, A. Olesińska, M. Masternak, J. Orłowski, Ordynacja podatkowa. Komentarz. Tom II, Toruń 2007, s. 47 oraz B. Adamiak, J. Borkowski, R. Mastalski, J. Zubrzycki, Ordynacja podatkowa. Komentarz, Wrocław 2004, s. 486.
} 
o wpłaceniu podatku. Jednocześnie wyłączenie wójta jako pracownika urzędu wyłącza go od udziału w postępowaniu, co powoduje brak rozwiązania problemu, kto powinien wydać interpretację indywidualną. Konsekwentnie należałoby wyłączyć podległych mu pracowników urzędu gminy. W sytuacji przyjęcia konieczności stosowania art. 130 § 1 pkt 2 Ordynacji podatkowej, który wyłącza od udziału w sprawie zarówno wójta, jak i wszystkich innych pracowników, brak natomiast możliwości wydania interpretacji przez podmiot inny niż właściwy organ podatkowy, ponieważ obowiązujące przepisy nie przewidują możliwości wyznaczenia do prowadzenie tych spraw innego samorządowego organu podatkowego.

Należy ocenić, że brak wyłączenia samorządowego organu podatkowego I instancji w sytuacji złożenia przez gminę wniosku o wydanie indywidualnej interpretacji przepisów prawa podatkowego stanowi lukę w prawie i w tym zakresie zasadna jest nowelizacja przepisów.

\section{Wyłączenie organu I instancji od załatwienia sprawy związanej z wymiarem zobowiązań podatkowych gminy}

Wątpliwości dotyczące wyłączenia organu podatkowego powstają także w sytuacji postępowań podatkowych, w których stroną jest gmina. Sytuacje takie występują najczęściej, gdy gmina jest współwłaścicielem nieruchomości i powstaje konieczność wydania decyzji określającej wysokość zobowiązania podatkowego w podatku od nieruchomości lub załatwienia sprawy związanej z wymiarem opłaty za gospodarowanie odpadami komunalnymi.

Analiza regulacji dotyczących wyłączenia samorządowego organu podatkowego prowadzi do wniosku, że wyłączenie to nie ma miejsca w sprawach, w których podatnikiem jest gmina. Z treści powoływanego wyżej art. 132 § 1 Ordynacji podatkowej wynika bowiem, że wójt, burmistrz oraz prezydent miasta podlegają wyłączeniu tylko od załatwiania spraw dotyczących ich zobowiązań podatkowych lub innych spraw normowanych przepisami prawa podatkowego. Nie można przyjąć, że o wyłączeniu organu w analizowanej sytuacji decyduje końcowa treść powyż- 
szego przepisu, z której wynika, że wyłączenie następuje również w „innych” sprawach normowanych przepisami prawa podatkowego. Z literalnej wykładni przepisu wynika bowiem, że zwrot „ich”, zawężający stosowanie przepisu do przypadków, w których sprawa dotyczy faktycznie osoby wójta, burmistrza lub prezydenta miasta, odnosi się również do spraw „innych” (tj. niezwiązanych z wymiarem). Sprawa związana z wymiarem podatku gminie nie może być zatem uznana za „inną sprawę normowaną przepisami prawa podatkowego".

Podstawą do wyłączenia wójta, burmistrza lub prezydenta miasta w analizowanym wypadku nie jest także art. $130 \S 1$ pkt 2 Ordynacji podatkowej, który przewiduje wyłączenie pracownika urzędu gminy (miasta) w sytuacji pozostawania ze stroną w takim stosunku prawnym, że rozstrzygnięcie sprawy może mieć wpływ na ich prawa i obowiązki. Ewentualne uznanie za wyłączonego na podstawie powołanego przepisu wójta, burmistrza lub prezydenta miasta jako pracowników urzędu wyłączy bowiem tylko ich od udziału w postępowaniu, nie rozstrzygając kwestii tego, kto sprawę powinien załatwić. Podkreślić należy, że problemu ryzyka braku bezstronności nie załatwia również ewentualne wydanie decyzji w stosunku do gminy przez pracownika upoważnionego do załatwienia spraw przez wójta, burmistrza lub prezydenta miasta na podstawie art. $143 \S 1$ Ordynacji podatkowej. Z kolei w sytuacji uznania, że wyłączenie przewidziane w art. $130 \S 1$ pkt 2 Ordynacji podatkowej obejmuje wszystkich pracowników urzędu gminy (stanowisko takie jest zajmowane w praktyce stosowania przepisów dotyczących wyłączenia pracowników w postępowaniu administracyjnym, co umożliwia wyznaczenie przez organ wyższego stopnia innego organu do załatwienia sprawy) brak możliwości rozpoznania sprawy przez inny samorządowy organ podatkowy. Przepisy Ordynacji podatkowej nie przewidują bowiem - w przeciwieństwie do art. $26 \S 3$ k.p.a. - by w sytuacji braku możliwości rozpoznania sprawy na skutek wyłączenia od udziału w postępowaniu wszystkich pracowników urzędu gminy wyznaczony został inny organ podatkowy. Zaznaczyć należy, że możliwość wyznaczenia do załatwienia sprawy innego organu podatkowego na skutek braku możliwości jej załatwienia z uwagi na wyłączenie 
pracowników została przewidziana w art. $130 \S 5$ Ordynacji podatkowej wyłącznie w odniesieniu do samorządowych kolegiów odwoławczych.

Podsumowując, należy ocenić, że brak wyłączenia organu podatkowego $\mathrm{w}$ sytuacji postępowania w sprawie wymiaru zobowiązania podatkowego gminy, szczególnie w sytuacji, gdy z uwagi na współwłasność nieruchomości zachodzi solidarna odpowiedzialność za zobowiązania podatkowe, wydaje się nie gwarantować bezstronności organów podatkowych i w tym zakresie konieczna jest nowelizacja przepisów.

\section{Wyłączenie członka samorządowego kolegium odwoławczego od udziału w postępowaniu prowadzonym w trybie nadzwyczajnym}

Analizowane regulacje z zakresu wyłączenia pracowników organów odnoszą się do członków samorządowego kolegium odwoławczego. Jednocześnie w związku z orzekaniem przez samorządowe kolegia odwoławcze na posiedzeniach w składach trzyosobowych, stosowanie tych przepisów wywołuje wątpliwości odnośnie do wyłączenia członków kolegiów w sytuacji zaskarżania rozstrzygnięć, w wydaniu których brali oni udział.

Zgodnie z art. $130 \S 1$ pkt 6 Ordynacji podatkowej członek samorządowego kolegium odwoławczego podlega wyłączeniu od udziału w postępowaniu w sprawach dotyczących zobowiązań podatkowych oraz innych spraw normowanych przepisami prawa podatkowego, w których brał udział w wydaniu zaskarżonej decyzji. Obecnie w orzecznictwie wątpliwości nie wywołuje konieczność wyłączenia członków samorządowych kolegiów odwoławczych od udziału w postępowaniu odwoławczym lub zażaleniowym na skutek zaskarżenia rozstrzygnięć wydanych przez kolegium $^{8}$. Jednocześnie powstaje wątpliwość dotycząca tego, czy członek

8 Zob. uchwała składu siedmiu sędziów NSA z dnia 22 lutego 2007 r., II GPS 2/06, CBOSA oraz wyrok Trybunału Konstytucyjnego z dnia 15 grudnia 2008 r., P 57/07, które jakkolwiek zapadły na gruncie k.p.a., to tezy w nich zawarte mogą być odnoszone do problematyki wyłączenia członków samorządowych kolegiów odwoławczych $\mathrm{w}$ postępowaniu podatkowym. 
kolegium, który brał udział w wydaniu rozstrzygnięcia w postępowaniu odwoławczym, może brać następnie udział w postępowaniach prowadzanych w trybach nadzwyczajnych związanych ze wzruszaniem decyzji ostatecznych (tj. stwierdzenia nieważności decyzji, wznowienia postępowania bądź uchylenia lub zmiany decyzji) ${ }^{9}$. W orzecznictwie sądów administracyjnych wykształciła się linia orzecznicza, zgodnie z którą istnieją podstawy wyłączenia członków organu kolegialnego od orzekania w sprawie wniosku o stwierdzenie nieważności decyzji, jeżeli członkowie ci orzekali w trybie „zwykłym” w tej sprawie ${ }^{10}$. Uzasadniając pogląd, będący rozwinięciem tez zawartych w powołanych uprzednio wyrokach NSA z dnia 22 lutego 2007 r. oraz TK z dnia 15 grudnia 2008 r., sądy uznawały, że postępowaniu wywołanym wnioskiem o stwierdzenie nieważności decyzji muszą towarzyszyć standardy i gwarancje przewidziane przez ustawodawcę dla postępowania wywołanego wniesieniem odwołania, w tym także respektowania zasady ustalonej w art. $130 \S 1$ pkt 6 Ordynacji podatkowej. Spotkać można również wyroki, w których sądy kwestie związane z wyłączeniem pracowników traktują jeszcze bardziej restrykcyjnie, uznając, że w sytuacji, gdy członek kolegium brał udział w wydaniu decyzji ostatecznej, a następnie brał udział tylko w wydaniu postanowienia dotyczącego wszczęcia postępowania o wznowienie postępowania zakończonego tą decyzją ostateczną na podstawie art. $243 \S 1$ Ordynacji podatkowej, decyzja wydana w wyniku wznowienia postępowania narusza art. $130 \S 1$ pkt 6 Ordynacji podatkowej, nawet jeżeli członek ten nie brał udziału w jej wydaniu ${ }^{11}$.

9 Opisywany problem dotyczy także w takim samym stopniu postanowień wydawanych w postępowaniu podatkowym.

10 Tak m.in. wyrok Wojewódzkiego Sądu Administracyjnego z dnia 10 maja 2011 r., I SA/Rz 137/11, CBOSA; wyrok WSA z dnia 16 marca 2012 r., I SA/Rz 44/12, CBOSA; wyrok WSA z dnia 20 marca 2012 r., I SA/Rz 51/12, CBOSA; wyrok WSA z dnia 19 kwietnia 2012 r., I SA/Rz 165/12, CBOSA.

11 Wyrok WSA z dnia 28 maja 2013 r., I SA/Rz 265/13, CBOSA. W doktrynie zwraca się natomiast uwagę na to, że przesłanka wyłączenia pracownika organu z art. 130 § 1 pkt 6 Ordynacji podatkowej powinna być wiązana tylko z fazą decyzyjną, tj. podpisanie projektu decyzji lub udziału w podjęciu uchwały - tak B. Adamiak, J. Borkowski, R. Mastalski, J. Zubrzycki, Ordynacja..., s. 492 oraz C. Kosikowski (red.), L. Etel (red.), R. Dowgier, P. Pietrasz, S. Presnarowicz, Ordynacja podatkowa. Komentarz, Warszawa 2006, s. 515. 
Powyższe poglądy wyrażone w orzecznictwie należy uznać za wadliwe z uwagi na to, że w sposób zbyt szeroki interpretują przesłankę wyłączenia przewidzianą w art. $130 \S 1$ pkt 6 Ordynacji podatkowej. Analizowany przepis stanowi bowiem o wyłączeniu pracownika, który brał udział w wydaniu zaskarżonej decyzji, co nie odnosi się do sytuacji złożenia wniosku o uruchomienie postępowania w trybie nadzwyczajnym. Jednocześnie w najnowszym orzecznictwie NSA odchodzi się od opisanej wyżej linii orzeczniczej, przyjmując słusznie, że jakkolwiek wniosek o wszczęcie postępowania w trybie nadzwyczajnym obejmuje zbadanie legalności decyzji ostatecznej, to jednak wszczyna on odrębne postępowanie, którego celem jest rozpoznanie odmiennej sprawy od rozstrzygniętej uprzednio, tj. ustalenie, czy postępowanie lub wydana w jego wyniku decyzja dotknięte są jedną $\mathrm{z}$ kwalifikowanych wad prawnych ${ }^{12}$. NSA przyjmuje, że w tej sytuacji nie znajduje zastosowania art. $130 \S 1$ pkt 6 Ordynacji podatkowej i okoliczność uczestniczenia przez członków samorządowego kolegium odwoławczego w wydaniu decyzji w postępowaniu prowadzonym w trybie zwykłym nie stanowi przeszkody do brania udziału w podjęciu rozstrzygnięcia w sprawie prowadzonej w trybie nadzwyczajnym.

Podzielając w pełni stanowisko zajmowane przez NSA, zwrócić należy jednocześnie uwagę na to, że w wypadku części przesłanek wzruszenia decyzji w trybie nadzwyczajnym, postulować należy wprowadzenie regulacji przewidujących wyłączenie członka samorządowego kolegium odwoławczego, o ile brał on udział w sprawie. Wydaje się, że jest to szczególnie istotne w wypadku niektórych przesłanek wzruszenia decyzji w trybie nadzwyczajnym, w tym przykładowo w sytuacji zarzutu rażącego naruszenia prawa (art. $247 \S 1$ pkt 3 Ordynacji podatkowej) lub wydania decyzji bez podstawy prawnej (art. $247 \S 1$ pkt 2 Ordynacji podatkowej). W tych sytuacjach kontrola legalności rozstrzygnięcia ostatecznego wymaga, by z uwagi na wymóg zachowania bezstronności członek kolegium, który rozpoznał sprawę, nie brał udziału w kolejnych postępowaniach

12 Tak wyrok NSA z dnia 17 października 2014 r., II FSK 622/13, CBOSA. 
dotyczących weryfikacji wydanego przez niego rozstrzygnięcia. W tym zakresie konieczna wydaje się zatem nowelizacja przepisów.

\section{Wnioski}

Przeprowadzona analiza regulacji prawnych prowadzi do wniosku, że ze stosowaniem przepisów dotyczących wyłączenia samorządowych organów podatków oraz ich pracowników związane są liczne problemy, w tym - co najistotniejsze - regulacje te nie znajdują zastosowania we wszystkich tych sytuacjach, w których pojawia się ryzyko braku bezstronności organu lub jego pracowników. Wadliwość analizowanych unormowań wynika z faktu, że ustawodawca, konstruując przepisy, nie uwzględnił specyfiki samorządowych organów podatkowych. Zaznaczyć należy jednocześnie, że często z krytyką co do braku bezstronności spotyka się już sam fakt orzekania w sprawach z zakresu podatków i opłat lokalnych przez samorządowe organy podatkowe. Jednocześnie ochronę praw podatników gwarantują w tym wypadku struktura organów podatkowych, związana z rolą samorządowych kolegiów odwoławczych jako organu, który jest niezależny od jednostek samorządu terytorialnego, oraz kontrola sądowa rozstrzygnięć wydanych w postępowaniu podatkowym.

Konieczna jest zatem nowelizacja obowiązujących przepisów w zakresie dotyczącym wyłączenia samorządowych organów podatkowych od wydawania indywidualnych interpretacji przepisów prawa podatkowego dla gmin, wyłączenia tych organów od załatwienia spraw związanych z zobowiązaniami podatkowymi gminy oraz wyłączenie od udziału w wydaniu decyzji w trybie nadzwyczajnym członka samorządowego kolegium odwoławczego, który brał udział w wydaniu rozstrzygnięcia w postępowaniu odwoławczym lub zażaleniowym. Zaznaczyć należy, że propozycje zmian legislacyjnych wydają się szczególnie istotne obecnie, w związku z trwającymi pracami nad zmianami regulacji prawnych ogólnego prawa podatkowego, w wyniku których uchwalona zostanie nowa ordynacja podatkowa. 
Paweł Majka

\section{Bibliografia:}

Adamiak B., Borkowski J., Mastalski R., Zubrzycki J., Ordynacja podatkowa. Komentarz, Unimex, Wrocław 2004.

Babiarz S., Dauter B., Gruszczyński B., Hauser R., Kabat A., Niezgódka-Medek M., Ordynacja podatkowa. Komentarz, Lexis Nexis, Warszawa 2007.

Brzezicki T., Morawski W., Gmina jako podatnik podatku od nieruchomości, „Przegląd Podatków Lokalnych i Finansów Samorządowych” 2010, nr 10, s. 9-12.

Brzeziński B., Kalinowski M., Olesińska A., Masternak M., Orłowski J., Ordynacja podatkowa. Komentarz. Tom II, TNOiK, Toruń 2007.

Dzwonkowski H., Zgierski Z., Procedury podatkowe, Difin, Warszawa 2006.

Kosikowski C. (red.), Etel L. (red.), Dowgier R., Pietrasz P., Presnarowicz S., Ordynacja podatkowa. Komentarz, Dom Wydawniczy ABC. Wolters Kluwer Polska, Warszawa 2006. 